\title{
Gross Split Contract Framework Regulation on the Caring for People
}

\section{Kirana Intaniasari}

Faculty of Law, Universitas Sebelas Maret Surakarta, Indonesia

Email Coresponden: kiranaintaniasariı@gmail.com

\begin{abstract}
This study aims to determine the model of oil and gas governance in Indonesia in terms of the interests of the State to protect natural resources that should be controlled for maximum use for the prosperity of the people. This study is based on the results of normative legal studies that are descriptive. The type of data used is secondary data obtained from literature study data collection techniques, which are then analyzed by carrying out systematic interpretation of the law. Systematic means, making a classification of written legal materials, to facilitate the work of analysis and construction. The results of this study show that oil and gas management arrangements began in the Dutch colonial period and continue to change with the times up to now, specifically the regulation of upstream oil and gas. Upstream oil and gas management has changed several times, namely the Concession system, the Contract of Work system, Production Sharing Contract (PSC) and finally the Gross Split Production Sharing Contract. The emergence of Gross Split aims to improve the PSC system and improve the efficiency and effectiveness of oil and gas production sharing patterns. Even though Gross Split still has weaknesses, but when compared to the previous system, Gross Split is more in line with the country's goal of being as broad as possible for the people.
\end{abstract}

Keywords: Mining; Gross Split; Welfare State.

\begin{abstract}
Abstrak
Penelitian ini bertujuan untuk mengetahui model tata kelola migas di Indonesia ditinjau dari kepentingan Negara untuk melindungi sumber daya alam yang seharusnya dikuasai untuk dipergunakan sebesar-besarnya demi kemakmuran rakyat. Kajian ini didasarkan atas hasil kajian hukum normatif yang bersifat deskriptif. Jenis data yang digunakan berupa data sekunder yang diperoleh teknik pengumpulan data studi pustaka, yang selanjutnya dianalisis dengan melaksanakan penafsiran hukum secara sistematis. Sistematis berarti, membuat klasifikasi terhadap bahan-bahan hukum tertulis tersebut, untuk memudahkan kerjaan analisa dan konstruksi. Hasil dari kajian ini menunjukkan pengaturan pengelolaan migas dimulai pada masa kolonial Belanda dan terus berubah mengikuti jaman hingga saat ini, khususnya pengaturan mengenai hulu migas. Pengelolaan hulu migas sudah berubah beberapa kali, yaitu sistem Konsesi, sistem Kontrak Karya, Production Sharing Contract (PSC) dan yang terakhir adalah Kontrak Bagi Hasil Gross Split. Munculnya Gross Split bertujuan untuk memperbaiki sistem PSC dan meningkatkan efisiensi serta efektifitas pola bagi hasil produksi migas. Walaupun Gross Split masih ada kelemahan, tetapi jika dibandingkan dengan sistem sebelumnya, Gross Split lebih sesuai dengan tujuan negara yaitu sebasar-besarnya untuk rakyat.
\end{abstract}

Kata Kunci: Pertambangan; Gross Split; Kesejahtraan Rakyat. 


\section{Introduction}

Indonesia is a country with a wealth of very abundant natural resources. This wealth is a gift from the All-Powerful God who has a very important role to create a just and prosperous Indonesian society. The Constitution of the Unitary State of the Republic of Indonesia of 1945 (Constitution of 1945) stipulates in Article 33(2) that the State controls the output divisions which are essential to the State and which control the livelihoods of the people. What is clarified in paragraph (3) of Article 33 is that the earth, water and natural resources contained therein are controlled by the state and used for the greater prosperity of the people. The article prescribes that the state's control of natural resources must be fully for the people 's prosperity. (Rumokoy, Nike K., 2016)

One rich resource in Indonesia is oil and gas (oil and gas). Indonesia is undeniably very dependent on natural resources such as oil and gas. Based on Pertamina data for 2013 , the total national demand for petroleum was 77.00 million KL, while the capacity of domestic refinery production was only 38.10 million $\mathrm{KL}$, resulting in a deficit of 38.9 million KL or around 51 per cent in 2013 (Rachmad Hardadi, 2015). Indonesia's high dependence on petroleum shows that petroleum energy is vital and revampi the regulations regulating the management of oil and gas in Indonesia are currently Law No. 22 of 2001 on Oil and Gas (Oil and Gas Act). (Chandranegara Ibnu Sina, 2017)

In Decision No. 36 / Puu-X/2012 relating to Decision No. 002 / PUU-I/2003 of 21 December 2014 concerning the testing of the Oil and Gas Code, the Constitutional Court gave meaning in Article 33 of the Republic of Indonesia 's Constitution of 1945 as to the principle of state control in Article 33 of the Republic of Indonesia 's Constitution of 1945 The conception of state control is a public law term similar to the theory of common sovereignty adhered to in the Republic of Indonesia Constitution of 1945, in both the political and economic fields. In understanding people's sovereignty, it is the people who are recognized as the source, owner and at the same time the highest authority in the life of the state, according to the doctrine of "the people, the people and the people." It underlined from that decision that the people gave the state the mandate to hold: (M. Ilham F Putuhena, 2015)

1. The policyprocedure.

2. Management steps the government's management role with the authority to issue and revoke the registration, registration and concession facilities.

3. Regulations, the regulatory role of the State shall be exercised by the DPR and the Government by legislative authority, and by the Executive.

4. Management, management role shall be exercised through the shareholding process and/or through the State as an institutional 
instrument. The government uses its power over the capital of that wealth to be used for the people 's greatest prosperity.

5. Toezichthoudensdaad, the task of state oversight is performed in order to supervise and monitor so that the operation of state control over these resources is effectively performed for the full benefit of the people.

The state has jurisdiction over natural resources with the right to power, which are the absolute right of the citizens given to the state to administer it so that it can be used for the greater benefit of the people. In other words, people do not have the ability to govern and handle it on their own, as there would be a power struggle that can lead to bloodshed. Moreover, it is also forbidden for the state to abuse power authority over natural resources which are essentially given by the people. (Gulam Dalula May Kafabih \& Volta Firdaus, 2015)

In general, the oil and gas industry comprises five phases of activity, namely exploration, exploitation, processing, transport, and marketing. These five core activities can be divided into two, namely upstream and downstream (downstream) activities. Under Article 1 point 7 of the Oil and Gas Rule, Upstream Business Activities are business activities which are central or focused on business activities related to exploration and extraction. The Upstream Business Activities referred to are conducted and regulated by a Cooperation Agreement (Article 6 subsection 1 of the Oil and Gas Act). Whereas Article 1(10) of the Oil and Gas Law explains that Downstream Business Activities are core business activities or depend on refining, transportation, storage and/or business activities. Downstream business operations as alluded to are performed under a Business License (Article $7(1)$ of the Oil and Gas Act)

Cooperation arrangements for managing and regulating upstream business operations have been changed numerous times from the colonial period of the Netherlands to the present. The amendment aims to look for cooperation contracts which are more in line with the Republic of Indonesia 's Constitution of 1945, namely to protect natural resources which should be regulated for full use for people 's prosperity. The new Cooperation Contract is a Production Sharing Contract with a gross split scheme in place after the implementation of the Gross Split Production Sharing Contracts Ministerial Regulation No. 8 of 2017. The problem with this research is whether the Gross Split Production Sharing Contract is in line with the constitution of the state, namely protecting natural resources that should be regulated for optimum use for people 's prosperity? 


\section{Research Methods}

This type of research is descriptive normative legal research. This study uses secondary data in the form of primary legal materials, secondary legal materials, and tertiary legal materials. Data collection techniques in normative legal research carried out with literature study of legal materials. Processing of tangible material activities to systematize written legal materials. In this case the processing of legal materials is carried out by means of classification according to the classification of legal materials and compiling the results of the research systematically and logically, meaning that there is a relationship and the relationship between legal materials with other legal materials to get a general picture of the results of the research. The legal material is then analyzed by interpreting the law.

\section{Discussion}

\section{Gross Split Mining Political Issues}

Management of oil and gas in Indonesia underwent several policy developments during its development. The Dutch government had found and mined oil and gas from Indonesian land by forming a Dutch government-owned corporation (the Royal Dutch and Batafsche Petrolium Maatschappij) before Indonesia 's independence. American oil companies, such as Standard Oil of New Jersey and Standard Oil of New York, began entering Indonesia in 1912. The Dutch government set up a joint venture between the Dutch and American governments, called Nederlandsch Indische Aardolie Maatschappij (Niam), in the regions of Jambi, Bunyu, and North Sumatra, so as not to be rivaled by American firms. The end of the Dutch colonial era entering the early 1940 s and transitioning to the Japanese occupation era, namely in 1942-1945. Japan 's objective of occupying Indonesia was to control natural resources, especially oil, to support Japan 's war potential and to support its industry. Japan, which invaded Indonesia at the time, caused Japanese ownership of previously managed properties, including oil and gas assets in Indonesia, to fall into the hands of the Dutch. Via previous Dutch holdings, Japan obtained information and data about the abundant oil resources in Indonesia. In 1944 Japan discovered the Minas Field, Riau, Southeast Asia's largest oil field. (Abdul Kadir Jaelani, 2015)

After Indonesian independence, President Soekarno's government took over all Dutch-owned companies in Indonesia, such as plantation companies and Netherlands-owned oil companies, and their oil wells. The Indonesian government had started producing its own oil and gas in the early days of independence, but still hadn't exported it overseas. The Soekarno government implemented a concession-system policy from 1946-1959 in the activities of oil and gas mining. Then only in October 1960 did the government allow government legislation in lieu of the Oil and Gas Mining Law (PERPPU) No. 44 of 1960. In this Perppu, before the birth of Law No. 8 of 1971 concerning the State Oil and Gas Mining Company (Pertamina Act), the Government implemented a Work Agreement or Contract of Employment regime for the management of oil and gas in Indonesia. After Pertamina was founded as a state-owned corporation, 
and it turned out that the corporation was experiencing rapid development with the issuance of the Pertamina Act. In addition to succeeding in becoming the world's largest exporter of LNG, Pertamina's oil production rose from 740,000 barrels a day in 1969 to 1,620,00o barrels a day in 1979. (Handayani I.G.A.K.R, As'Adi E, Hamzah.G, Leonard T, Gunarto G, 2017)

However, the existence of Pertamina was challenged in 1999 because of the Oil and Gas Bill of 1999. The bill was supposed to replace the law of Pertamina which implied the dissolution of Pertamina. Nonetheless, the Oil and Gas Bill application faced a lot of criticism from various parties and eventually the DPR rejected the 1999 Oil and Gas Bill, and Pertamina was not dissolved. The life of Pertamina as a single entity in Indonesia's oil and gas industry ended after the Oil and Gas Act (Oil and Gas Act) Law No. 21 of 2001 was issued. The Oil and Gas Legislation is the first step in establishing a more open market in the oil industry in order to enable liberalisation. Pertamina will be working as one of the oil and gas industry players classified fairly with other industry participants in the Oil and Gas Act. In the Oil and Gas Act, Indonesia's oil and gas industry is regulated to be divided into the Upstream and Downstream sectors, where the upstream sector is controlled by the Upstream Oil and Gas Special Task Force (SKK Migas) and the downstream sector is controlled by the Upstream Oil and Gas Regulatory Agency (BPH Migas). (Surachman A, Handayani I.G.A.K.R, Taruno Y., 2017)

As a government delegate, SKK Migas is charged with upstream control through a Cooperation Deal. Based on Article 1 point 19 of the Oil and Gas Act, Cooperation Contracts are Profit Sharing Contracts or other types of cooperation contracts in Exploration and Exploitation activities that are of greater benefit to the State and the results are used for the greatest welfare of the nation. Based on its growth, Indonesia has experienced many changes in the upstream activities of the Cooperation Contract system since the Dutch era up until 2006. First is the concession scheme adopted from the Netherlands period until the beginning of independence, where the company owns all the revenue in the concession and the state collects revenues only in the form of gross and tax. The second is the method of contract of service, in this method the company is converted from a concessionaire to a state contractor. So the state and companies share the proceeds of oil and gas sales but the state 's position is still very limited in supervisory capacity, management control is still in the company's hands. The Contract of Work scheme was eventually scrapped and changed to a Profit Sharing Contract (PSC). Under this program mining authority is granted to the client. (Handayani I.G.A.K.R, Sulistiyono A, Leonard L, Gunardi A, Najicha F.U., 2018)

The government provided a PSC contract system because in the Republic of Indonesia Constitution of 1945 this structure was deemed to reflect Article 33, rather than the previous concession system. That is because, the state remains the master of natural resources in this system. It is also predicted that the PSC program would have a significant long-term effect on Indonesia, by having the country control its own oil and gas resources. The PSC 's application in Indonesia was motivated by the need for greater position for the nation by providing the authority to control upstream oil and gas activities. In this system the business is 
only granted the mining authority with the distribution concept while the government shares the results of net output with the oil and gas contractors in this system. The estimation of the government's revenue share with the oil and gas company is performed quarterly. Essentially, the contractor provides what's required in upstream operations such as capital and the necessary resources. All expenses must be approved by the government, because the government will return the capital to the contractor. Replacement is known as cost recovery, the cost of replacement if the upstream operations have been performed and the effects of oil and gas exploration have been identified, or discoveries of oil and gas reserves that can be produced. At the other hand, if oil reserves which are not suitable for extraction are not discovered, then all forms of expenditures spent by exploration contractors will not be substituted. (Subekti R, Sulistiyono A, Handayani I.G.A.K.R., 2017)

Government Regulation No 79 of 2010 on Recoverable Operating Costs and Income Tax Treatment in the Upstream Oil and Gas Business Sector (PP Cost Recovery) provides the legal basis for the introduction of a cost recovery scheme for PSCs. Nevertheless, the PSC poses a number of issues in its application. In addition to the cost recovery policy issue, the rise and fall in oil prices also defines income distribution. Fees and taxes which also affect state revenue with a revenue sharing system result in government revenue not receiving an initial percentage of 85 percent of oil and gas production profits. Cost recovery to be paid 100 per cent is considered to be very detrimental to the state, depending on the size of the contractor's operating costs. And the recovery of costs paid often need not be matched with the results obtained from the output. (Algonin A.A, Shleag A.M, Handayani I.G.A.K.R, Setyono P., 2017)

Basically, cost recovery is applied to return the costs incurred by investors in carrying out the exploration and exploitation of the produced oil and gas. These costs may be recovered in the process after receiving consent from an agency / body with the authority to repay running costs. As for recovery of costs, the Government must pay for recovery of costs. Different methods of bribery, markup cost recovery, misuse of state finances, have forced the state to bear high costs in carrying out oil and gas exploration. The cost recovery rate was USD 15.13 billion, or Rp, in 2012. 147668800 thousand. The amount of oil and gas expense recovery to be paid by the state (in trillion US dollars) for 2001-2005 is 4.35; 5.06 ; 5.52; 5.60; and 7.68 from the data circulating. And if it is on average at a Rp exchange rate. It's about Rp, 9,ooo / US. 50 Million per annum. Thus the recovery of costs has in reality many shortcomings in its implementation. So if the cost recovery fails to apply, the nation can go through more losses year after year. (Akhmaddhian S, Hartiwiningsih, Handayani I.G.A.K.R., 2017)

Many losses arising from the cost recovery scheme, the government eventually released Permen ESDM No. 8 of 2017 relating to Gross Split Profit Sharing contracts. The Gross Split method provides a total output division that is achieved without the running cost returning process. This program offers assurances that the contractor can bear the development risk completely, so that the government will not have to pay for recovery of costs. The government believes that this option is more realistic and effective because government 
intervention is much reduced, effective, and the difficulty of auditing, administration, and lobbying is reduced. The most important difference between PSC and Gross Split is the lack of cost recovery at Gross Split. Regardless of this, the level of income sharing between PSC and Gross Split is different, in the PSC the level of revenue sharing is 85 per cent for the nation and 15 per cent for the contractor, the figure does not include the recovery of costs. However, the profit share in Gross Split is 57 percent for the state and 43 percent for petroleum generating contractors and 52 percent for the state and 48 percent for natural gas generating contractors. Furthermore, there are factors other than cost recovery, including First Tranche Petroleum (FTP), which are not in the Gross Split profit sharing arrangement.(Abdul Kadir Jaelani, 2015)

FTP in compliance with Government Regulation No 79 of 2010 relating to Refundable Operating Costs and Treatment of Income Tax in the Upstream Oil and Gas Business Field is a certain amount of crude oil and/or natural gas generated from a work area in one calendar year, until deducting operating and controlling cost of production (own use) returns. FTP works in such a way that at the start of output there is assurance about state revenue. Historically, FTP has been attributed to the second-generation PSC where oil and gas recovery costs have reached $100 \%$, and it has the possibility that all production output will be used to restore cost recovery, and FTP is required for state revenue certainty. But FTP is no longer required in the Gross Split contract as all the sections that the government and the contractor will obtain will be clear at the beginning of the contract

Regulation of the Minister of Energy and Mineral Resources No. 52 of 2017 amending the Regulation of the Minister of Energy and Mineral Resources No. 8 of 2017 on Gross Split Profit Sharing Contracts and setting out in Article 6 of the Regulation of the Minister of Energy and Mineral Resources No. 8 of 2017 'Approval for Field Creation, the volume of benefit sharing shall be Which will be obtained through cost recovery between the Government and the contractor.

The Gross Split scheme also controls that the supplies and facilities for the working contractors must remain the state property. This is mentioned in Article 21 of the Energy and Mineral Resources Minister's Regulation No. 8 of 2017 on Gross Split Contracts. State ownership of assets is considered necessary for technology transfer in this region, so the assets in Gross Split will remain state owned property. At the end of the year, the government also released Government Regulation No. 53 of 2017 concerning tax compliance of Gross Split Profit Sharing Contracts in Upstream Oil and Gas Business Activities. It has, of course, complemented the Gross Split program structure, so that the Gross Split production sharing deal is incompatible from ordinary industry. In Article 6 of Government Regulation No. 53 Year 2017 on Tax Treatment in Upstream Oil and Gas Business Activities With Gross Split Profit Sharing Contracts it was specified that the operational costs incurred by the contractor can be measured as an aspect of revenue reduction in the sharing of production from oil and gas in the estimation of taxable revenue.(Abdul Kadir Jaelani, 2015) 


\section{Gross Split Contract Framework Regulation on the Caring for People}

According to Subianto Tjakrawerdaja, the management of oil and gas on the basis of Article 33 of the Republic of Indonesia 's Constitution of 1945 must include seven constitutional features, namely: first, the economy aims at achieving collective prosperity for all citizens, as explained specifically in the description of Article 33 of the Republic of Indonesia 's Constitution of 1945 Second, the participation of the citizens in control, the cycle of development and enjoy the results. This is in accordance with the language found in Article 33(1) and (4) of the Republic of Indonesia Constitution of 1945. Thirdly, in accordance with the concept of Article 33(4) of the Republic of Indonesia 's Constitution of 1945, namely fair performance, the economy must be conducted using a free market system based on fair competition and the State's position and authority to intervene in the event of market failure. Fourthly, as required by Article 33(1) and (3) of the 1945 Constitution of the Republic of Indonesia, the role of the State must be safeguarded, in particular with regard to national economic planning, the development and enforcement of laws, and the implementation of service programs and community empowerment, taxes on liberation, subsidies, etc.( Rahman M.D, Sadath M.N, Giessen L., 2016)

Fifth, BUMN as one of the foundations of economic activity controls important branches of development, and controls many people's lives. This is explicitly stated in Article 33(2) of the Republic of Indonesia Constitution of 1945. Sixth, cooperatives as foundations of the people 's economy must be understood in a spirit of co-operation with SOEs and the private sector, as well as the commercial business organizations of individuals. Seventh, an example of an equitable relationship between cooperatives, SOEs and the private sector must be the national economy. This idea is enshrined in Article 33(1) of the Republic of Indonesia Constitution of 1945. Such constitutional provisions will be converted into a whole collection of legislation relating to oil and gas management. People 's greatest prosperity is the aim of all management and exploitation of national natural resources. This goal is seen as an interest that can not be ignored, because it is coveted by every citizen as well as being the mandate of the constitution, and is the responsibility of the state as a consequence of the right to control the country itself. Thus every exploitation and use of natural resources is adjusted to the objective (doelmatig).

There is a belief from the Indonesian Nation which is stated in the 1945 Constitution of Indonesia that Indonesia is a welfare state. One of them is listed in the Preamble to the 1945 Constitution of the Republic of Indonesia which clearly stipulates that one of the staatsidee of the Indonesian State is to advance public welfare. In its body, the 1945 Constitution also formulated the conception of the welfare state into the phrase "prosperity of the people". The phrase is contained in Article 33 paragraph 3 of the 1945 Constitution of the Republic of Indonesia contained in the Chapter of the National Economy and Social Welfare which states that the earth, water and natural resources contained therein are controlled by the state and are used to the greatest prosperity of the people. The article is a norm that expressly regulates state interference in the economy and 
characterizes the adoption of the concept of welfare state in Indonesia, it must also be implemented and become the basis in making Indonesia's economic policy, including in the petroleum sector. Petroleum sector policy needs to be analyzed with the concept of welfare state considering that the sector is important for the country and controls the lives of many people. For this reason, the state should play an active role in the petroleum sector, by realizing democratic state life that is ultimately able to realize the prosperity of the people. As an important sector for the country and controlling the lives of many people, if there is a mistake in making policies in the petroleum sector, it can massively harm the people.( Handayani I.G.A.K.R, Sulistiyono A, Leonard L, Gunardi A, Najicha F.U., 2018)

Looking at the welfare state theory, that Indonesia in the concept of welfare refers to the concept of social welfare development, which is a series of planned and institutionalized activities aimed at improving the standards and quality of human life. Welfare state is very closely related to social policy (social policy) which includes the strategy and efforts of the government in improving the welfare of its citizens. The Indonesian nation in carrying out community, nation and state life has a legal ideal (rechtsidee). The ideals of the Indonesian nation are the guides in the direction of the life of the Indonesian people. The opening of the 1945 Constitution of the Republic of Indonesia is the legal ideal of the Indonesian people to build an independent, sovereign, just and prosperous nation. Gross Split can be seen as a bright spot for the oil and gas industry which requires fast and profitable handling, so that the scale of oil and gas production can be increased to be distributed wisely by the state. There is a promising possibility that the Gross Split policy which cuts down the cost recovery system will benefit the country. Cost recovery system is very detrimental to the country and very far from the concept of welfare state. Cost recovery is more profitable for oil and gas companies in Indonesia, including foreign companies. (Subekti R, Sulistiyono A, Handayani I.G.A.K.R., 2018)

Efforts to realize the prosperity of the people can be seen from the implementation of the gross split profit sharing contract. The gross split implementation is the implementation of Article 33 of the 1945 Constitution within the framework of the welfare state, because it can be the current solution amid limited capital and technology. Upstream oil and gas management cannot be separated from the country's goals and direction of state management, namely to achieve welfare and social justice, so that constitutionally becomes an important concern in national development, the state's position in relation to oil and gas natural resources, the state has the freedom to make regulations, policies, management, management and supervision of oil and gas resources. The management function is the first and foremost form of state control to achieve the greatest prosperity of the people. The government must prioritize state control in the first place, namely managing oil and gas natural resources which brings greater benefits to the people.(Abdul Kadir Jaelani, 2015)

The emergence of Gross Split aims to improve the efficiency and effectiveness of oil and gas production sharing patterns. Even though Gross Split still has weaknesses, but when compared to the previous system, Gross Split is 
more in line with the state's goal, which is as much as possible for people's prosperity.

\section{Conclusion}

Legal provisions covering upstream oil and gas production have undergone a variety of changes since the colonial period in the Netherlands until now. Oil and gas management cannot be isolated from the objectives and purpose of state management of the country, namely to achieve welfare and social justice, so that constitutionally it becomes a major concern in national development. The country's position regarding natural resources for oil and gas has the right to make laws, legislation, management, management and oversight of oil and gas resources. In the first place, the government must give priority to state power, namely the management of natural resources from oil and gas that bring greater benefits to the people. The advent of the PSC system and Gross Split are government attempts to prosper the people, but the PSC system has many problems in its implementation and is deemed to be detrimental to the country. Then Gross Split was born, which aims to strengthen the PSC system and improve the quality and productivity of the sharing patterns of oil and gas production. While Gross Split still has drawbacks, Gross Split is more in line with the country 's goal of being as wide as possible to the citizens as opposed to the previous system. People 's greatest prosperity is the aim of all management and exploitation of national natural resources. This goal is seen as an interest that cannot be ignored, because it is coveted by every citizen as well as being the mandate of the constitution, and is the responsibility of the state as a consequence of the right to control the country itself. The production and use of natural resources therefore tailored to the goals.

\section{References}

Abdul Kadir Jaelani, "Politik Hukum Putusan Mahkamah Konstitusi Nomor 36/PUU-X/2012 Tentang Pembubaran BP MIGAS: Upaya Mengembalikan Kedaulatan Negara Menuju Perlindungan HAM”, Jurnal Panggung Hukum, Volume 1, Nomor 1 Tahun 2015.

Handayani I.G.A.K.R, As'Adi E, Hamzah.G, Leonard T, Gunarto G. "Relationship between Energy Consumption in International Market and Indonesia Prices Regulation", International Journal of Energy Economics and Policy, Vol.7, Issue 5 Tahun 2017.

Surachman A, Handayani I.G.A.K.R, Taruno Y. "Effect of Globalization on Establihment of Water Resource Law: A Practice in Indonesia", International Journal of Economic Research, Volume 14, Number 13 Tahun 2017 . 
Arif Jumari, "Potensi Pelanggaran Pengelolaan Limbah Bahan Berbahaya dan Beracun”, Jurnal Bestuur, Volume 7, No. 2 (2019).

Abdul Kadir Jaelani, "Implementasi Daluarsa Gugatan Dalam Putusan Peradilan Tata Usaha Negara di Indonesia”, Pena Justisia: Media Komunikasi dan Kajian Hukum, Volume 18, Nomor 2 Tahun 2019.

Handayani I.G.A.K.R, Sulistiyono A, Leonard L, Gunardi A, Najicha F.U. "Environmental Management Strategy in Mining Activities in Forest area Accordance with the Based Justice in Indonesia", Journal of Legal, Ethical and Regulatory Issues Volume 21, Issue 2, 2018.

Subekti R, Sulistiyono A, Handayani I.G.A.K.R. "Solidifying The Just Law Protection For Farmland To Anticipate Land Conversion". International Journal of Economic Research, Volume 14, Number 13 Tahun 2017.

Algonin A.A, Shleag A.M, Handayani I.G.A.K.R, Setyono P. "Variation of Environmental Awareness among the Student in Government High Schools in Solo City Indonesia”. International Journal of Applied Engineering Research Volume 9, Number 21. 2014.

Akhmaddhian S, Hartiwiningsih, Handayani I.G.A.K.R. “The Government Policy of Water Resources Conservation to Embodying Sustainable Development Goals: Study in Kuningan, Indonesia”. International Journal of Civil Engineering and Technology. Volume 8, Issue 12 Tahun 2017.

Chintami Dian Balenina, "Partisipasi Masyarakat dalam Pengelolaan Desa Sampah Mandiri di Desa Kalisoro, Tawangmangu, Kabupaten Karanganyar”, Jurnal Bestuur, Volume 7, No. 1 (2019).

Abdul Kadir Jaelani, "Politik Hukum Putusan Mahkamah Konstitusi Nomor 36/PUU-X/2012 Tentang Pembubaran BP MIGAS: Upaya Mengembalikan Kedaulatan Negara Menuju Perlindungan HAM", Jurnal Panggung Hukum, Volume 1, Nomor 1 Tahun 2015.

Yusriando Yusriando, "Konstruksi Sistem Jaminan Sosial Nasional Bidang Kesehatan”, Jurnal Bestuur, Volume 7, No. 2 (2019).

Solikah Ana Estikomah, "Aspek Hukum Import Sampah Plastik”, Jurnal Bestuur, Volume 7, No. 2 (2019).

Rahman M.D, Sadath M.N, Giessen L. "Foreign Donors Driving Policy Change in Recipient Countries: Three Decades of Development Aid towards Community-Based Forest Policy in Bangladesh," Forest Policy and Economics 68 (July 2016).

Dharmasaputra, Metta dkk. (2014). Wajah Baru Industri Migas Indonesia. Jakarta: PT Katadata Indonesia.

Sutedi, Adrian. 2012. Hukum Pertambangan. Jakarta: Sinar Grafika.

Dalula May Volta, Gulam dan Firdaus Kafabih 2015. Reformulasi Sistem Bagi Hasil Melalui Kontrak Bagi Produksi Guna Mewujudkan Kedaulatan Migas, Jurnal Perhimpunan Mahasiswa Hukum Indonesia, Vol.1, No.1.

Hernandoko, Andrey dan Mochammad Najib Imanullah. 2018. Implikasi Berubahnya Kontrak Bagi Hasil (Product Sharing Contract) Ke Kontrak Bagi 
Hasil Gross Split Terhadap Investasi Minyak Dan Gas Bumi Di Indonesia. Jurnal Privat Law Vol. VI No 2 Juli - Desember 2018.

K. Rumokoy, Nike. 2016. Pelanggaran Hukum Terhadap Penggunaan Minyak Dan Gas Bumi (Migas) Yang Terkandung Di Dalam Wilayah Hukum Pertambangan Indonesia Oleh Pihak Yang Tidak Berwenang, Vol.22/No.5/Januari / 2016 Jurnal Hukum Unsrat.

Putuhena, M. Ilham F. 2015. Politik Hukum pengelolaan Hulu Migas Pasca Putusan Mahkamah Konstitusi. Jurnal Rechtsvinding Volume 4, Nomor 2.

S. Chandranegara, Ibnu, Desain Konstitusional Hukum Migas untuk SebesarBesarnya Kemakmuran Rakyat. Jurnal Konstitusi, Volume 14 Nomor 1 Tahun 2017.

Tjakrawerdaja, Subiakto. 20o8. Menunggu UU Induk Mengenai Perekonomian Nasional, Reform Review (Jurnal untuk Kajian dan Pemetaan Krisis). Volume II Nomor 1.

Abdul Kadir Jaelani, "Politik Hukum Putusan Mahkamah Konstitusi Nomor 36/PUU-X/2012 Tentang Pembubaran BP MIGAS: Upaya Mengembalikan Kedaulatan Negara Menuju Perlindungan HAM”, Jurnal Panggung Hukum, Volume 1, Nomor 1 Tahun 2015. 